\title{
Histology of the gastrointestinal tract from Bothrops jararaca and Crotalus durissus
}

\section{Aspectos histológicos do trato gastrointestinal de Bothrops jararaca e Crotalus durissus}

\author{
Izabel Carolina Vargas Pinto GOGONE${ }^{1}$; Marcelo Pires Nogueira de CARVALHO'; \\ Kathleen Fernandes GREGO²; Sávio Stefanini SANT’ANNA²; \\ Francisco Javier HERNANDEZ-BLAZQUEZ3; José Luiz CATÃO-DIAS ${ }^{1}$ \\ ${ }^{1}$ Universidade de São Paulo, Faculdade de Medicina Veterinária e Zootecnia, \\ Departamento de Patologia, Laboratório de Patologia Comparada de Animais Silvestres, São Paulo - SP, Brazil \\ ${ }^{2}$ Instituto Butantan, Laboratório de Herpetologia, São Paulo - SP, Brazil \\ ${ }^{3}$ Universidade de São Paulo, Faculdade de Medicina Veterinária e Zootecnia, \\ Departamento de Cirurgia, Laboratório de Anatomia Microscópica e Imuno-Histoquímica, São Paulo - SP, Brasil
}

\begin{abstract}
Recent studies have discussed the importance of snakes, going beyond the context of Public Health (snakebites). Promising research demonstrates the utility of snake venom in several fields, including oncology, diagnosis, anticoagulant therapy, and pain treatment. Nevertheless, there are still gaps in the basic knowledge on these animals, specifically regarding the histological characterization of the gastrointestinal tract, which ultimately hinder comparative histology and pathology studies. In this context the present study intends to contribute with the advance of current knowledge on snake histology by describing and analyzing histological samples of the gastrointestinal tracts of Bothrops jararaca and Crotalus durissus. Samples were collected from 12 individuals (six from each species), up to 6 months of age and equally distributed between males and females. Histological slides were prepared from the organs collected and were stained with hematoxylin and eosin, periodic acid-Schiff and alcian blue. The slides were photographed with a high-resolution camera to create a portfolio representative of the histology of the gastrointestinal systems of these animals.
\end{abstract}

Keywords: Digestive tract. Herpetology. Morphology. Snakes.

\section{Resumo}

$\mathrm{Na}$ atualidade, a importância das serpentes extravasa a conotação em saúde pública (acidentes ofídicos), e pesquisas promissoras têm demonstrado a utilidade dos venenos das serpentes em diversas áreas como oncologia, diagnóstico, terapia anticoagulante e tratamento da dor. Ainda assim, existem lacunas no conhecimento básico sobre esses animais, tais como a caracterização histológica do seu sistema gastrointestinal, que se tornam obstáculos para estudos nos campos da histologia e patologia comparadas. Nesse contexto, o presente trabalho pretende contribuir com o avanço do conhecimento sobre histologia de serpentes a partir da descrição e análise histológica de amostras do trato gastrointestinal de exemplares das espécies Bothrops jararaca e Crotalus durissus. Para tanto, foram coletadas amostras de 12 indivíduos com até seis meses de idade, seis por espécie (distribuídos igualmente entre machos e fêmeas). A partir dos órgãos colhidos, lâminas histológicas foram preparadas e coradas pela técnica de hematoxilina e eosina, bem como PAS com Alcian Blue. As lâminas foram fotografadas por câmera de alta resolução, resultando em um portfólio representativo da histologia do sistema gastrointestinal desses animais.

Palavras-chave: Trato digestivo. Herpetologia. Morfologia. Serpentes. 
Correspondence to:

Izabel Carolina Vargas Pinto Gogone

Universidade de São Paulo,

Faculdade de Medicina Veterinária e Zootecnia,

Departamento de Patologia, Laboratório de Patologia

Comparada de Animais Silvestres

Av. Orlando Marques de Paiva, 87

CEP 05508-270, São Paulo, SP, Brazil

e-mail: izabel,gogone@gmail.com

Received: 30/05/2017

Approved: 27/07/2017

\section{Introduction}

Histological descriptions in the context of organismal physiology facilitate understanding cell and tissue function, inferring on histopathological findings. Gaps are common in the field of snake histology, especially regarding the digestive tract, mainly because most of the histological studies on the order Squamata focus on the suborder Lacertilia, whereas few focus on the Ophidia (ABDEEN et al., 2013). Such gaps are a hindrance to histopathological characterizations, limiting scientific applicability and the development of research on snake conservation and biodiversity. Nonetheless, numerous scientific findings, discussed below, indicate the scientific potential of these species, especially Bothrops jararaca (jararaca) and Crotalus durissus (rattlesnake).

Bothrops jararaca has a broad distribution in southeastern South America (ALMEIDA-SANTOS, 2005); In Brazil it is usually associated with the Atlantic Forest and anthropogenic areas (HARTMANN et al., 2003). The jararaca is a viviparous, semi-arboreal, and nocturnal snake that is most active during the rainy season. It feeds mostly on rodents and birds (ALVES et al., 2000).

The genus Crotalus is represented by only one species in Brazil, C. durissus. Approximately five of the known $C$. durissus subspecies inhabit different regions of the country. These snakes are robust and have a characteristic rattle at the end of the tail (RICARDI, 2010).

The venom of $B$. jararaca has been investigated in several studies on cancer therapy (SILVA et al., 1996; SANTOS et al., 2008) and chronic parasitic diseases (DEOLINDO et al., 2005; RICARDI, 2010), as well as in studies on the formulation of diagnostic techniques and antihypertensive drugs (MARSH, 2002), including Captopril and, more recently, Evasin:

In turn, the protein "enpak" (endogenous pain killer), which has an analgesic power nearly 600 times that of morphine, was obtained from the toxin produced by C. durissus (MACHADO et al., 2008), which also has potential antimicrobial action (AGUIAR, 2014), antiviral action (RUSSO et al., 2014), antifungal action (NEVES et al., 2015), immunomodulatory action (ALMEIDA et al., 2015), and antitumor action (RUDD et al., 1994).

As these animals become more important in our society there is a growing need for greater anatomical and morphological knowledge about species, predominantly those that play key roles in research and conservation. Many papers investigate the physiological aspects of the species, but there is clearly a gap regarding the morphological aspect (KHAMAS; REEVES, 2011).

The objective of the present study was to produce histological knowledge to aid in the investigation of histopathological findings to promote the animal, human, and environmental health and conservation.

\section{Materials and Methods}

The use of animals in the present study was approved by the Animal Ethics Committee of the School of Veterinary Medicine and Animal Sciences of the University of São Paulo, under number 2419200115, and by SISBIO (Authorization System and Information in Biodiversity) - license number 34863-3. Twelve snakes, six B. jararaca and six $C$. durissus specimens, up to six months of age and equally distributed between males and females were used in the present study.

The animals were kept individually in plastic boxes $(60 \times 40 \times 15 \mathrm{~cm})$ containing a substrate composed of corrugated cardboard and a plastic water dispenser that offered water ad libitum. The boxes were kept in acclimatized rooms with temperatures ranging from 25 to $27^{\circ} \mathrm{C}$, at approximately $60 \%$ relative humidity. It was decided to limit the scope of this study to the histology of the gastrointestinal tract of newborns animals so that, never having received food, there would be no bias due to type of intake.

The snakes were euthanized in $\mathrm{CO}_{2}$ chamber according to the guidelines of the CEUA/FMVZ/USP.

After necropsy, the samples collected were immediately immersed in 10\% formaldehyde solution for 24 hours and were then transferred to $70 \%$ ethanol.

The esophagus was collected whole and divided into approximately $1.0 \mathrm{~cm}$ fragments, which were classified as pre or post-cardiac, according to their relative topographic position regarding to the heart. The stomach 
was collected whole. The intestines followed the pattern of esophagus samples and were divided into $1.0 \mathrm{~cm}$-long fragments. Collected and fixed tissue fragments were processed and embedded in paraffin. Subsequently, $5.0 \mu \mathrm{m}$-thick sections were obtained and dyed with hematoxylin and eosin (H\&E), alcian blue $(\mathrm{AB})$, periodic acid-Schiff (PAS), and PAS/AB (PROPHET, 1992).

\section{Results}

Table 1 shows the biometric data of each animal used in this experiment.

A representative archive composed of approximately 500 high-definition images was obtained from the 198 analyzed and photographed sections. No statistical differences were found between either species or sexes. The following section describes the main histological characteristics observed in the respective fragments analyzed:

Table 1 - Biometric data of each animal used in the study, comprising identification code, species, sex, total weight, length between head and cloaca and the total length, from head to tail tip - São Paulo - 2014

\begin{tabular}{|c|c|c|c|c|c|}
\hline Identification & Species & Sex & Weight (g) & $\begin{array}{l}\text { Head-cloaca } \\
\text { length }(\mathrm{cm})\end{array}$ & $\begin{array}{c}\text { Total length } \\
(\mathrm{cm})\end{array}$ \\
\hline BJ01 & B. jararca & Male & 10,615 & 26,5 & 31,5 \\
\hline BJ02 & B. jararca & Male & 9,137 & 29,0 & 33,0 \\
\hline BJ03 & B. jararca & Female & 9,002 & 27,0 & 32,5 \\
\hline BJ04 & B. jararca & Male & 10,193 & 28,5 & 33,0 \\
\hline BJ05 & B. jararca & Female & 9,380 & 28,5 & 32,5 \\
\hline BJ06 & B. jararca & Female & 9,966 & 28,5 & 33,0 \\
\hline C01 & C. durissus & Male & 22,020 & 29,0 & 32,0 \\
\hline $\mathrm{CO} 2$ & C. durissus & Female & 20,874 & 31,0 & 33,5 \\
\hline $\mathrm{CO3}$ & C. durissus & Male & 22,020 & 30,5 & 33,0 \\
\hline C04 & C. durissus & Male & 19,466 & 27,0 & 30,0 \\
\hline C05 & C. durissus & Female & 18,611 & 32,0 & 34,5 \\
\hline $\mathrm{C} 06$ & C. durissus & Female & 18,206 & 30,0 & 32,0 \\
\hline
\end{tabular}

\section{Esophagus}

The cranial portion of the esophagus was composed of a mucosa lined with richly ciliated simple prismatic epithelium interspersed with mucus-secreting cells. The wall exhibited large folds capable of accommodating variable volumes of food. Below the epithelium was a lightly eosinophilic, very thin lamina propria containing blood vessels. The muscularis mucosae were not thick (especially in the more cranial portions of the esophagus, where the wall itself was thin) but was easily distinguishable. The submucosa was also thin, whereas the muscle layer (smooth fibers) was slightly thicker than the muscularis mucosae. The outermost layer of the wall consisted of an adventitia, given that up to the hiatus, the esophagus was in intimate contact with the other organs of the coelomic cavity.

More caudally, still within the portion anterior to the heart, the wall folds were maintained. The muscle layer was composed of fibers in two different directions (inner circular and outer longitudinal) and became thicker towards the caudal portion of the esophagus. Epithelial cilia were abundant and strongly stained with eosin. Lymphoid aggregates composed mainly of lymphocytes were located in the lamina propria. The esophagus immediately anterior to the heart maintained all of the characteristics of the cranial portions. 
The portion posterior to the heart (post-cardiac esophagus) exhibited some histological differences. In the mucosa, epithelial cilia became progressively sparse, and the epithelial cells themselves exhibited more elongated and less oval morphology. The lamina propria was characterized by a variable thickness and more easily detectable lymphoid aggregates. Mucosal folds were less longitudinal (rather flattened) but were still evident and more uniform than in the pre-cardiac portion. The muscularis mucosae maintained the thickness of the anterior segments. The submucosa and the muscle layer maintained their thickness or were slightly thicker. Smooth muscle bundles exhibited two directions: longitudinal (outer) and circular (inner).

In general, few changes were observed in the middle portion of the esophagus with respect to the previous portions. However, there was a gradual vanishing of epithelial cilia and a subtle increase in the amount of lymphoid aggregates in the mucosa. The epithelial morphology was constantly prismatic.

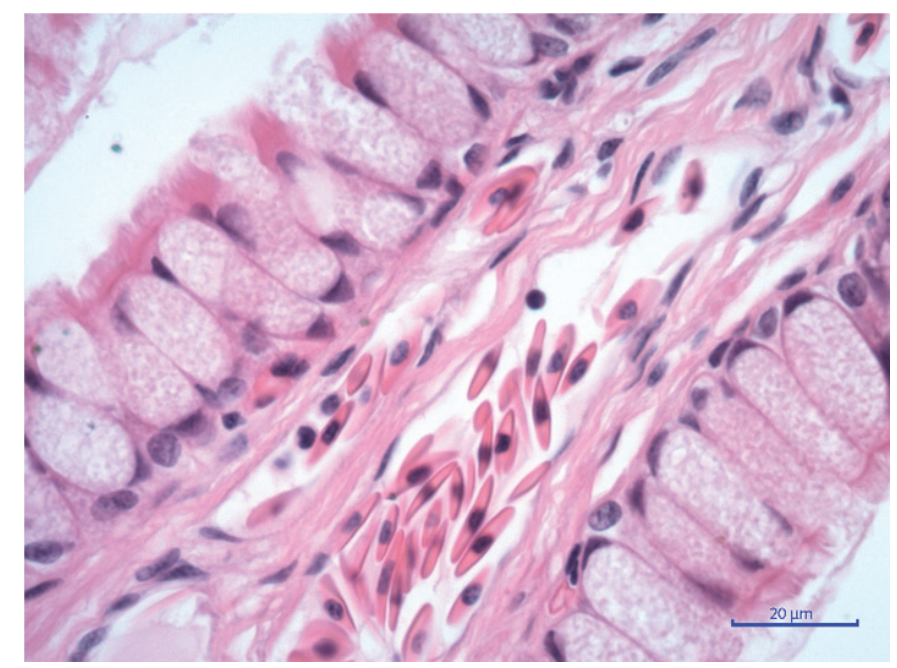

Figure 1 - Photomicrograph of the pre-cardiac esophagus, cranial portions of Bothrops jararaca. 40x magnification. H\&E. This figure illustrates crosssection of a wall projection, containing blood vessel that, being cut crosswise, exposes the content of erythrocytes. The epithelium lining the lamina propria is characterized by a prismatic simple epithelium, filled with mucous secretion (note the tracery content aspect of these cells); note the lumen richly coated with very delicate cilia
The wall of the esophagus immediately anterior to the stomach was clearly thicker than that of the initial cranial esophagus, which may be mainly related to the thickening of the muscle layer, the muscularis mucosae, and the submucosa. The mucosa was lined with simple prismatic epithelium interspersed with mucus-secreting cells. The lamina propria was relatively homogeneous and thin throughout the entire length of the esophagus, but the muscularis mucosae were thicker with respect to the previous portions.

The submucosa seemed reasonably homogeneous from the cranial to the caudal portions; however, it exhibited subtle thickening near the gastroesophageal transition.

The muscle layer was clearly visible and reached maximum thickness in the terminal portions of the esophagus. Smooth muscle bundles were arranged in both circular and longitudinal senses. The adventitia seemed slightly thicker than in the initial fragments and exhibited vascularization (Figures 1 to 3 ).

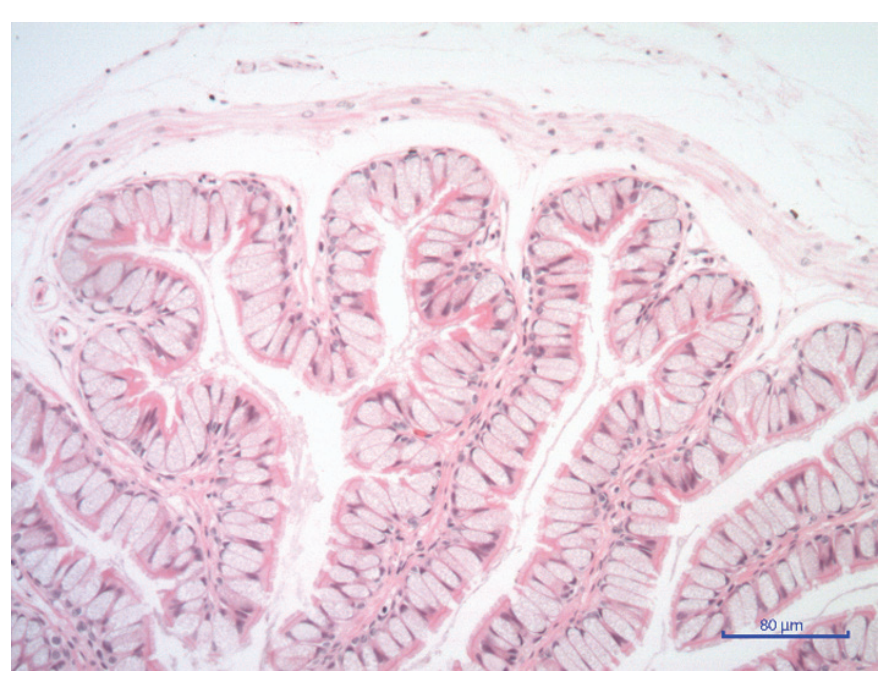

Figure 2 - Photomicrograph of the pre-cardiac esophagus, immediately anterior to the heart of Crotalus durissus. 10x magnification. H\&E. The image illustrates the constituent layers of the esophageal wall: Mucosa (composed of ciliated epithelium, prismatic, permeated by goblet cells filled with mucous content aspect "tracery" or "granular", lamina propria of connective tissue and thin muscularis mucosae), submucosa - very pale in the image - muscular layer, and gently eosinophilic staining adventitia 


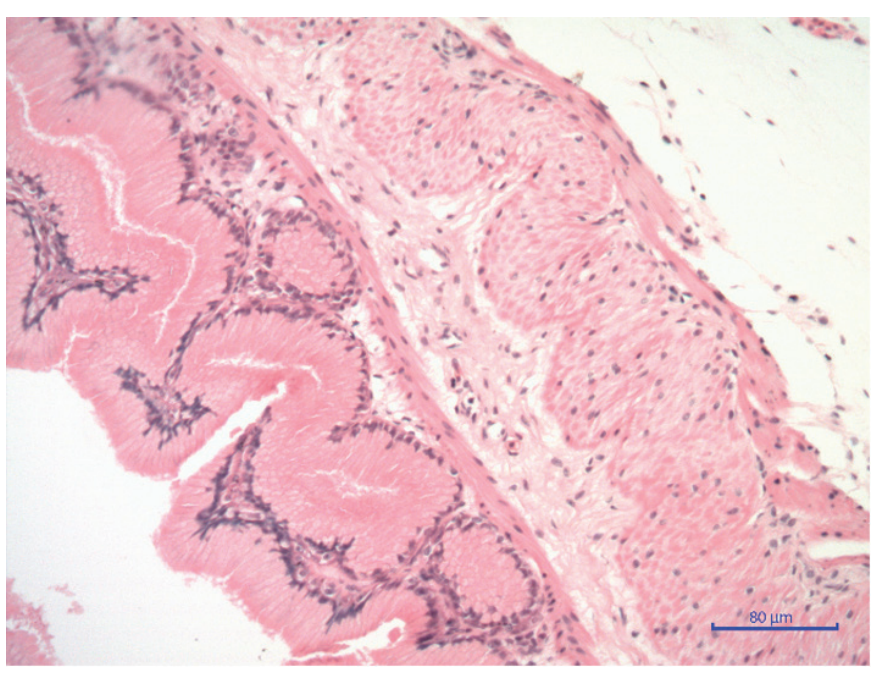

Figure 3 - Photomicrograph of the post-cardiac esophagus, final third of the posterior portion of the heart, Bothrops jararaca. 10x magnification. H\&E. This picture is fairly representative of the esophageal wall's layers, as well as the two directions - circular and longitudinal - smooth muscle bundles of muscle layer

\section{Stomach}

The macroscopic transition between the esophagus and the stomach was very clear. However, histologically, this transition was only distinguishable between the cardia and the fundus, as the cardia retained the morphology of the terminal portion of the esophagus, which confounds their distinction during histological reading.

In the microscopic analysis, the transition between the cardia and the fundus was very well defined. The cardia was composed of a mucosa with simple prismatic epithelium, thin lamina propria and muscularis mucosae, a submucosa and a muscle layer. The fundus, in turn, composed the main glandular portion of the stomach. The stomach wall in the fundic region thickened abruptly, and the mucosa became composed of a lining epithelium with non-ciliated simple columnar cells (cambered). In addition, there were neck cells, which were strongly stained with PAS, demonstrating the neutral character of the mucus, outlining the abundant gastric glands, which, in turn, were composed of oxyntopeptic cells (negative in PAS). The muscularis mucosae were thicker than in the esophagus.

The submucosa was richly vascularized and followed the projections of the mucosa to the lumen, which were proportionally wider and longer than those in the esophagus. The muscle layer of the wall was composed of two layers: one inner circular, and another outer longitudinal. The serosa was the outermost layer of the organ.
The final portion of the stomach, the pylorus, was also glandular, which makes it difficult to differentiate them (Figures 4 to 6).

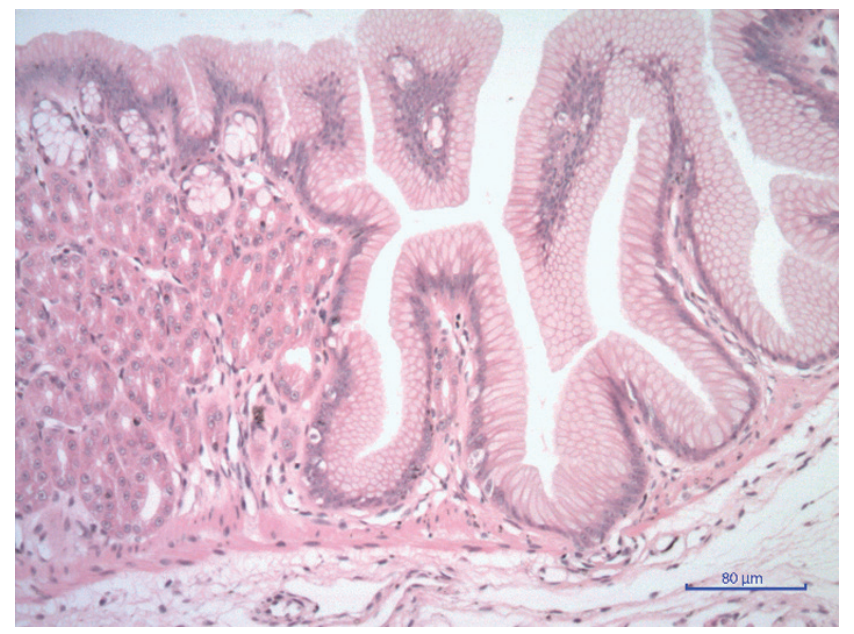

Figure 4 - Photomicrograph of the transition from cardia to fundus of the stomach, Crotalus durissus. 10x magnification. PAS. On the right edge of the picture it's possible to see a mucosa lined by simple prismatic epithelium, thin lamina propria and muscularis mucosae, and also the submucosa. Approaching the left of the figure there is the first gastric gland, which demarcates the transition to the fundic portion of the stomach; therefrom mucosa suffers an abrupt change, becoming more dense and rich oxyntopeptic glands and Neck Cells, as well as having more prominent muscularis mucosae

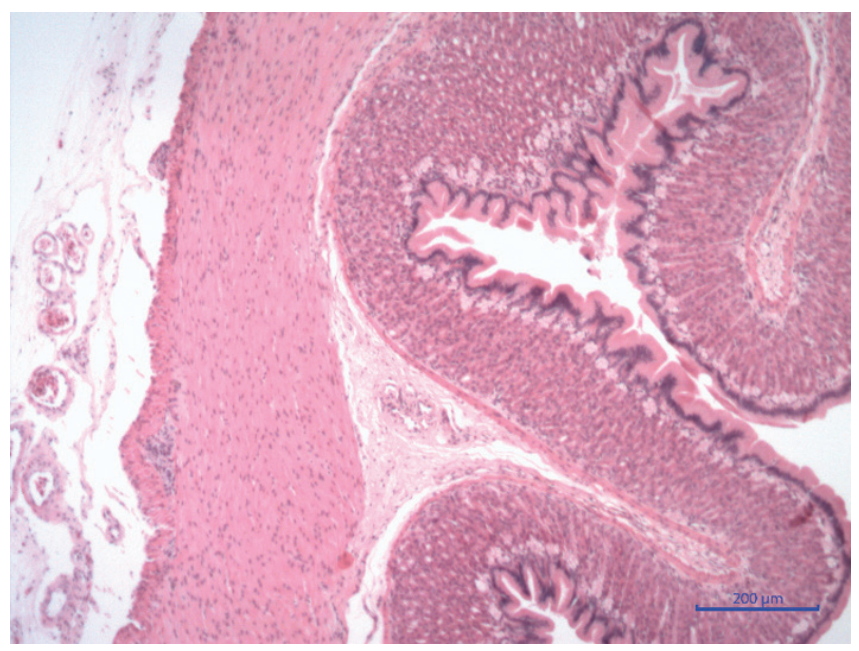

Figure 5 - Photomicrograph of the stomach wall. Bothrops jararaca. 4x magnification. H\&E. This crosscut illustrates the distribution between the layers of the gastric wall. The mucosa is made of the lining epithelium, glands - note the stratification of cell types that compose these structures -, lamina propria, and muscularis mucasae are quite evident in this figure. The submucosa is visibly protruding, following the mucosa into the lumen. The muscle layer is clearly thicker than found in the esophagus, even in the end portions, and it is arranged in bundles in the circular and longitudinal directions. Finally, note the serosa, richly vascularized 


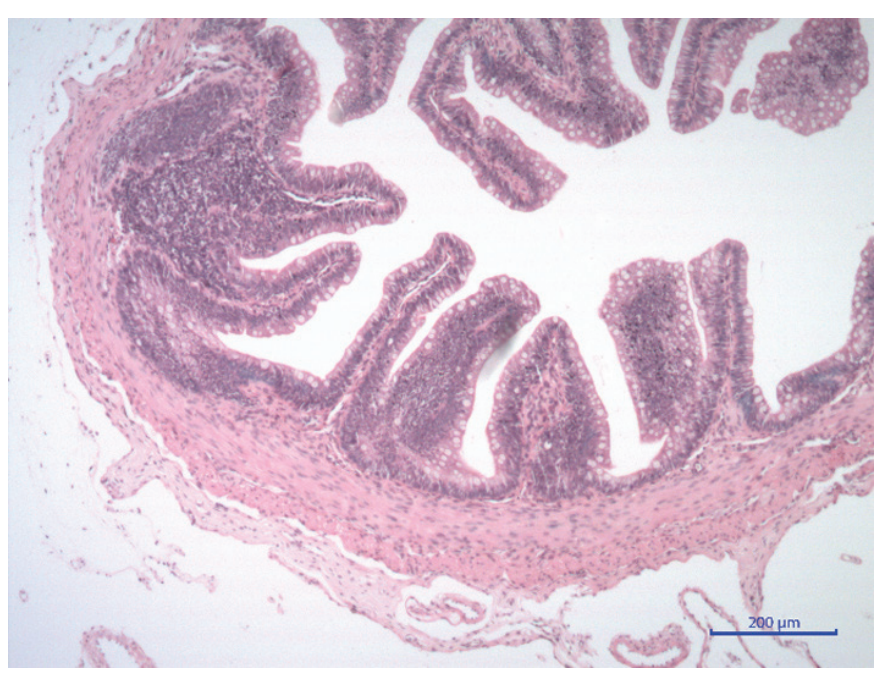

Figure 6 - Photomicrograph of the small intestine of Crotalus durissus. $4 \mathrm{x}$ magnification. H\&E. It is a representative cross-section of the layers of intestinal wall and morphology of the villi. It is worth mentioning the presence of lymphoid aggregate (on the left of figure) in the submucosa. The muscle layer has bundles in two directions and vascularized serosa is also quite distinguishable

\section{Small Intestine}

The transition between the pylorus and the duodenum was gradual. Specifically, the typical morphology of intestinal folds was observed, while pyloric glands were still present in the mucosa. The wall was thinner in the duodenum, especially because of the reduction of the muscle layer, but it was also thinner in the muscularis mucosae and in the submucosa.

After the transitional portion, the typical duodenum was observed. The wall was much thinner than that of the stomach, and its mucosa was lined with simple prismatic epithelium, formed by enterocytes and goblet cells, which projected, together with the usually thin lamina propria, into the lumen, thus composing the typical duodenal folds. After the transitional portion, the typical duodenum was observed. These intestinal folds were leaf-shaped, elongated and protuberant, and in the photomicrographs seemed to form a net that virtually covered the entire lumen of the organ, thus suggesting the composition of duodenal folds. A subtle, more prominently eosinophilic line over the epithelium represented the intestinal striated cuticles.

Goblet cells (strongly stained with PAS) were present between enterocytes, though in low numbers, and could be observed with some difficulty at lower magnifications, appearing as small pale spots on hematoxylin-eosin stained slides. As the histological analysis progressed in the caudal direction of the organ, these cells became progressively more abundant. The muscularis mucosae were very thin and did not follow the projections that formed the intestinal folds.

At times, the submucosa contained lymphoid aggregates, which became more numerous as the caudal portions of the intestine were reached. The muscle layer had internal and external bundles, which followed different directions (circular and longitudinal, respectively). Finally, the serosa was highly vascularized and stained pale pink using the hematoxylin-eosin technique, and it was formed by connective tissue, lined by mesotelials cells.

The jejunum and ileum were not easily distinguishable, as the epithelial structure was maintained in both portions. The topography of the organ associated with the morphology of the intestinal folds helps in the identification. By relating these data to the relative amount of goblet cells and lymphoid aggregates, it is possible to efficiently infer the intestinal portion in question. In contrast to the duodenum, which was marked by long intestinal folds and few goblet cells, the jejunum was characterized by equal numbers of folds and cells or more longitudinal intestinal folds, whereas the epithelium was especially permeated with goblet cells. Finally, the ileum exhibited flatter intestinal folds and the greatest amount of goblet cells with respect to all portions of the small intestine (Figures 7 and 8).

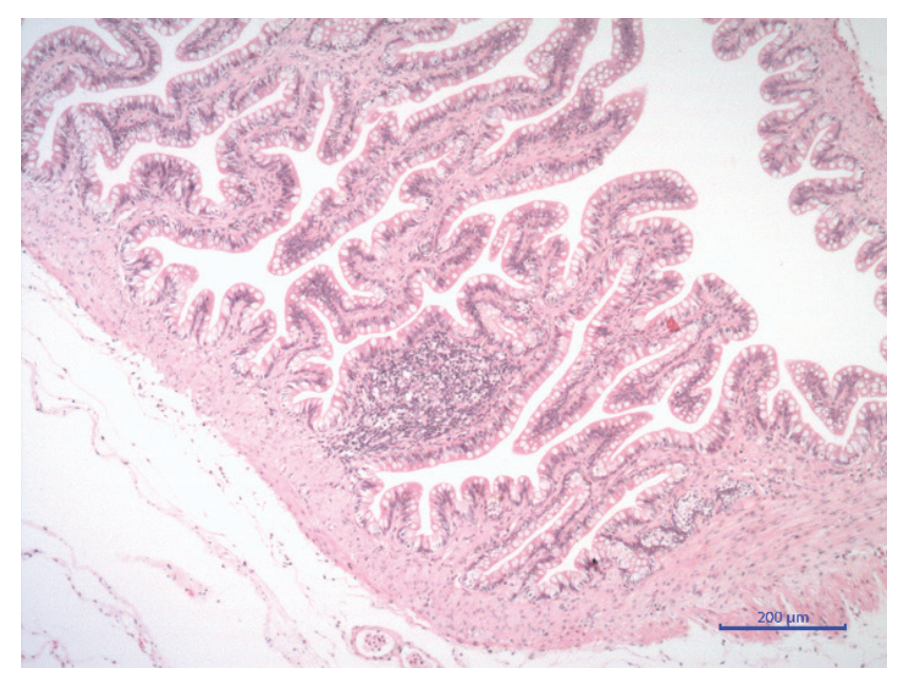

Figure 7 - Photomicrograph of the small intestine of Crotalus durissus. $4 \mathrm{x}$ magnification. $\mathrm{H} \& \mathrm{E}$. In this figure it is possible to see the wall layers (mucosa, submucosa, muscle layer, and serosa), specially the epithelium, interspaced with a big amount of goblet cells (pale spots). Note the lymphoid aggregate in the center of the figure 


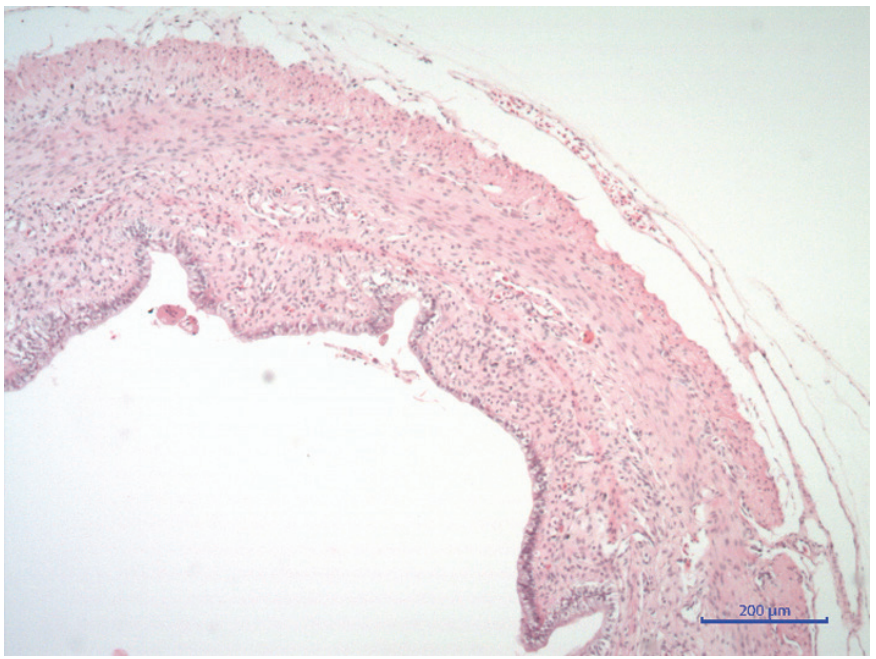

Figure 8 - Photomicrograph of the large intestine of Crotalus durissus. 4x magnification. H\&E. Cross-section. This figure illustrates the layers constituting the intestinal wall. It is noteworthy that the villi are noticeably flattened and goblet cells are present in large numbers; taking into account that it is the final portion of the thin intestine, it is possible to suggest that the portion corresponds to the ileum

\section{Large Intestine}

The studied snakes have no cecum. Thus, the histological readout of the colon and cloaca was sufficient to characterize the final fraction of the intestine.

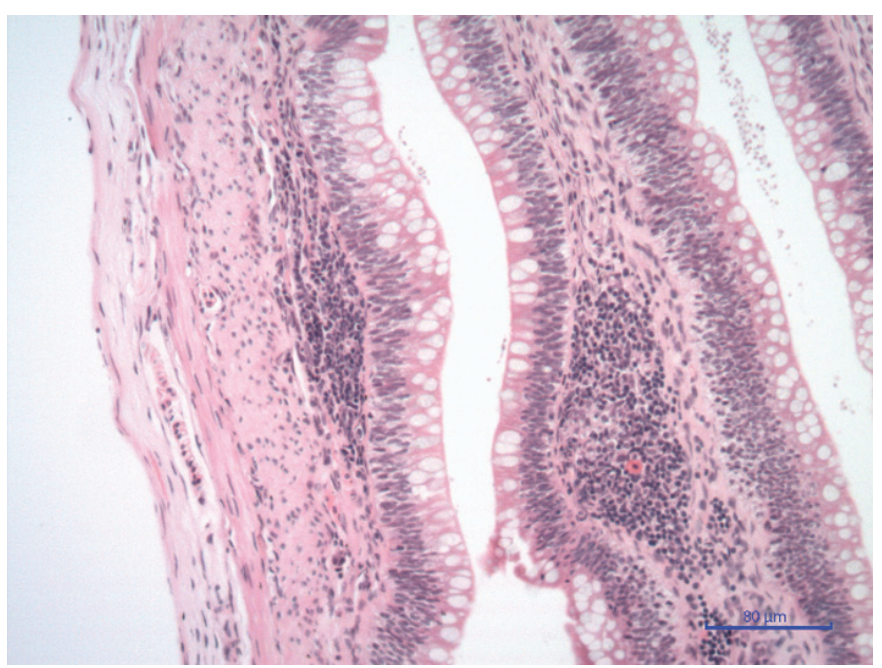

Figure 9 - Photomicrograph of the large intestine from Bothrops jararaca. 10x magnification. H\&E. It is possible to see many goblet cells and two lymphoid aggregates, which indicates significant presence of these structures in the fragment. From the left end to the right, there may be observed: serous, muscles bundles in two directions, submucosal lymphoid aggregate, and mucosal epithelium with richly interspersed goblet cells

The mucosa of the colon was composed of simple prismatic epithelium, interspersed with abundant goblet cells virtually lining it. The lamina propria and the muscularis mucosae were very thin, and both projected to form the intestinal folds, which, in this portion, were flattened or had a flat apex.

The submucosa harbored abundant lymphoid aggregates and was followed by the muscle layer, which also had bundles in different directions (longitudinal and circular). The serosa was thick and stained pale pink with eosin, the same standard of the other sections from the intestine.

In the studied samples, there were no changes in the structure of the intestinal wall of the cloaca, which remained histologically indistinguishable from the colon (Figure 9).

\section{Discussion}

Abundant research on the digestive physiology of snakes is available, while a morphological description is still quite limited (KHAMAS; REEVES, 2011).

Thus, comparing the data obtained by this experiment with the available literature, it is possible to conclude that the findings described here confirm that the predominant esophagus-lining epithelium of the studied samples was prismatic simple epithelium, which is compatible with previous works (FRYE, 1991; ABDEEN et al., 2013), although no pseudo-stratified epithelium has been found, as described by Khamas and Reeves (2011). The morphology of the esophageal epithelial cells seemed to undergo changes: while the cells were oval and round in the cranial portions, they were longer in the caudal esophagus portion. However, this finding has not been reported by other authors (FRYE, 1991; JACOBSON, 2007; KHAMAS; REEVES, 2011; ABDEEN et al., 2013).

Cilia were abundant only in the pre-cardiac portion of the esophagus and became progressively scarce after the heart. The presence of cilia was observed in previous studies (JACOBSON, 2007; KHAMAS; REEVES, 2011), and in the present study. Frye (1991) also did not report the presence of cilia; however, there is mentioned literature reporting the opposite. Esophageal glands, except for goblet cells, were absent in the descriptions of Abdeen et al. (2013), While Kharmas and Reeves (2011) deny the presence of these goblet cells in the esophageal epithelium in Pituophis catenifer, a difference that may be associated with the different species compared.

The esophageal wall exhibited a thickening in the cranial-caudal sense, especially regarding the muscle layer and, secondarily, the muscularis mucosae and even 
the adventitia, according to the terms used by Jacobson (2007), as similarly found in this work. Abdeen et al. (2013) describes that the esophageal-gastric transition is abrupt and that the mucosa of the gastric fundus, the main glandular portion of the organ, is composed of stratified columnar epithelium with cylindrical cells and glands, which, in turn, are outlined by neck cells (FRYE, 1991; JACOBSON, 2007). These gastric glands exhibit two clearly distinguishable cell types: one characterized by dark cells (pale blue stain or light basophilia) and the other by light cells (eosinophilic) (FRYE, 1991; JACOBSON, 2007). The points of discrepancy between the cited works involve the types and functions of the cells present in the gastric glands, the characterization of the cardiac and pyloric portions and, finally, the number of layers of the muscularis mucosae.

That said, it should be noted that although the authors of this work have described separately the cardia, the fundus, and the pylorus, it is merely a didactic differentiation, since at the same time the esophagus and cardia could not be distinguished, as pylorus and fundus could not either.

Frye (1991) and Helmstetter et al. (2009) describe the cardia as an epithelium identical to the esophagus, with an abrupt transition to the glandular epithelium of the fundic portion, which, in turn, is the major glandular portion of the stomach. The pyloric portion is characterized by a discrete reduction in the number of gastric glands, epithelial projections resembling intestinal folds, and a lining with a single, strongly eosinophilic cell type (FRYE, 1991). Thus, with respect to the fundus and the pylorus, the descriptions are very similar, in the sense of the present study.

However, Jacobson (2007) divided the stomach only in fundus and pylorus, with the latter portion characterized by shorter and less branched glands, still poorly distinguishable from the anterior portion.

This apparent discrepancy seems merely nominal to us and not analytical, given that Jacobson (2007) simply did not name the transition between the esophagus and cardia, as it is histologically indistinguishable and only macroscopically visible. The abrupt microscopic transition, which is a consensus between both works cited, occurs only between the cardia and the fundus, corroborating the findings of the present study.

Concerning the cell types constituting the gastric glands, the samples examined in the present study exhibited one type composed of a pale and heterogeneous cytoplasm and a flattened marginal basophilic nucleus (denominated "clear mucous cells" by Jacobson [2007] and "clear cells" by Frye [1991]) and a second type with a more strongly stained eosinophilic cytoplasm and a central basophilic nucleus (called "dark serous cells" by Jacobson [2007] and "chief cells" or "zymogenic cells" by Frye [1991]). Thus, there seems to be an agreement with the literature, given that even though different terms are used, the descriptions coincide with those observed in the present study.

The disagreement between the authors was about the functionality of cellular constituents types of gastric glands. Recent studies (Helmstetter et al., 2009), associated with the analysis of the resulting material of this research, led the authors to conclude that, in the same terms of Jacobson (2007), dark serous cells exert the combined function of pepsinogen and $\mathrm{HCl}$ secretion (and, thus, of zymogenic and parietal cells, respectively). Due to technical limitations, this function was not confirmed in the present study, but the authors consider it a reasonable speculation in need of experimental proof. This hypothesis is corroborated by Helmstetter et al. (2009), which called these dual purpose cells "oxyntopeptic". These conclusions were different from those drawn by Frye (1991), who claim that reptiles do not have parietal cells.

Concerning the number of layers of the muscularis mucosae, in the present study circular and longitudinal bundles were detected, corroborating the data reported by Jacobson (2007) and Abdeen et al. (2013). However, another work described the muscle layer as having three subdivisions: oblique, circular, and longitudinal (Frye, 1991).

Finally, regarding the intestine, Frye (1991) described the transition of the epithelia (from the pylorus to the duodenum) as abrupt, which differs from the findings described here. Specifically, pyloric glands were still present in the mucosa, while their folds exhibited a typical duodenal morphology, giving the transition a gradual aspect.

While Frye (1991) described the duodenum as having crypts (glands) of Lieberkühn in the deeper layers of the mucosa, other works (Jacobson, 2007; Helmstetter et al., 2009; Abdeen et al., 2013) disagreed as to the presence of these glands, as do the findings of the present study. In all samples collected within this experiment, we did not find any evidence of these glands, in line with the latter authors. Jacobson (2007) and Abdeen et al. (2013) stated that crypts are not present in snakes; thus, their function in 
renewing and substituting enterocytes might be performed by either analogous structures or cell division throughout each villus. Jacobson (2007) further reported the presence of Paneth cells and enteroendocrine cells composing the mucosa and, finally, affirmed that the remaining portions of the small intestine are not distinguishable from the duodenum.

According to Frye (1991), the epithelium lining the duodenal lumen is simple and columnar and has goblet cells that become more numerous towards the caudal portions of the small intestine. Furthermore, the submucosa contains lymphoid aggregates, which follow the same distribution reported for goblet cells; it is thin and has no Brünner glands, in contrast to higher vertebrates. The internal and external muscle layers are well developed. Finally, the serosa lines the portion of the intestinal wall that is in contact with the cavity. The results reported here confirm the description in these results.

The jejunum exhibited elongated intestinal folds, with less numerous glands and a higher abundance of goblet cells and lymphoid aggregates compared to the duodenum. Finally, the ileum as described by Frye (1991) has less elongated intestinal folds and is rich in lymphoid aggregates and goblet cells. Abdeen et al. (2013) did not report a morphological distinction between the duodenum and the ileum.

The divergences in the literature are more objective with respect to the small intestine. Regarding the portions of the small intestine, Jacobson (2007) characterized the duodenum in detail, claiming that it is not distinguishable from the jejunum and ileum. Frye (1991), in turn, and in agreement with what we believe to have demonstrated with our results, elaborated criteria to help the histologist identify the intestinal segments with a certain margin of certainty, including the morphology of the intestinal folds and the number of goblet cells, as described in this results.

In short, knowing the macroscopic topography of the fragment, the researcher can infer the portion of the small intestine being analyzed with reasonable reliability. Notably, samples from C. durissus seemed to exhibit an early increase in the number of goblet cells when compared to the analogous intestinal portions in B. jararaca, but this requires further quantitative demonstration in later studies.

It may be difficult to distinguish between the ileum and the cranial portion of the colon. Distinguishing criteria, though rather subjective, include the number of lymphoid aggregates in the submucosa (greater in the large intestine) and the morphology of the intestinal folds.

Frye (1991) ended the analysis of the gastrointestinal tract by describing the large intestine as a mucosa lined with simple columnar epithelium containing many mucins-secreting goblet cells, a submucosa filled with lymphoid aggregates, and a thinner lamina propria with respect to the previous portions. Other works reported that the caudal cloaca could have variable histology (FRYE, 1991; JACOBSON, 2007). In the present analyses, all samples exhibited simple columnar to cuboidal epithelium, interspersed with abundant goblet cells (ABDEEN et al., 2013), representing the highest proportional amount regarding the entire gastrointestinal tract.

Dividing the esophagus and intestines into $1.0 \mathrm{~cm}$ segments was found to be an adequate approach for the proposed analysis, as it enabled a gradual and controlled follow up of the characteristic changes of the epithelium, wall, and glands and a primary division of the esophagus (anterior and posterior to the heart), following the model formulated by Jacobson (2007). The same can be said about immediately fixing samples in $10 \%$ formaldehyde solution, which allowed for reliable representations of the histological condition (JUNQUEIRA; CARNEIRO, 2004). Thus, several dubious issues or issues not yet addressed in the literature could be elucidated in the present study.

\section{Conclusions}

Images and descriptions obtained in this study allowed several observations, which are: (1) The distribution of cilia in the esophagus, in cranial abundant portions and increasingly rare in the caudal direction; (2) the distinction between the stomach and the duodenum portions - the authors established clear histological differences between the esophagus (similar to the cardia), the fundus, and the pylorus (almost indistinguishable), clarifying the apparent discrepancies constants of literature; (3) the characterization of oxyntopeptic gastric cells, present in the fundus and the pylorus; (4) the elucidation about the number of muscle layers of the stomach as well as on the direction of the bundles, i. e., two distinct layers of muscles, with an external longitudinal and an internal circular; (5) in the intestine, according to these results, there were no Lieberkhün crypts. 


\section{Acknowledgements}

The authors would like to thank the Pathology Departament of the School of Veterinary Medicine and Animal Science, São Paulo State University for funding the original manuscript translation.

Moreover, we would like to thank the technical and

\section{References}

ABDEEN, A. M.; MOSTAFA, N. A.; ABO-ELENEEN, R. E.; ELSADANY, D. A. Anatomical studies on the alimentary tract of the Egyptian Typhlopid Snake. Journal of American Science, v. 9, n. 5, p. 504-517, 2013. doi: 10.7537/marsjas090513.65.

AGUIAR, C. S. Avaliação do potencial antimicrobiano do veneno total de serpentes dos gêneros Bothrops e Crotalus. 2014. 84 f. Dissertação (Mestrado em Biotecnologia) Universidade Federal da Bahia, Salvador, 2014.

ALMEIDA, C. S.; ANDRADE-OLIVEIRA, V.; CÂMARA, N. O. S.; JACYSYN, J. F.; FAQUIM-MAURO, E. L. Crotoxin from Crotalus durissus terrificus is able to down-modulate the acute intestinal inflammation in mice. PLoS One, 2015. doi: 10.1371/journal.pone.0121427.

ALMEIDA-SANTOS, S. M. Modelos reprodutivos em serpentes: estocagem de esperma e placentação em Crotalus durissus e Bothrops jararaca (Serpentes: Viperidae). 2005. 201 f. Tese (Doutorado em Ciências) - Universidade de São Paulo, São Paulo, 2005. doi: 10.11606/T.10.2005.tde-28062006-143529.

ALVES, M. L. M.; ARAUJO, M. L.; WITT, A. A. Aspectos da biologia reprodutiva de Bothrops jararaca em cativeiro (Serpentes, Viperidae). Iheringia, Série Zoologia, n. 89, p. 187-192, 2000. doi: 10.1590/S0073-47212000000200009.

DEOLINDO, P.; TEIXEIRA-FERREIRA, A. S.; MELO, E. J. T.; ARNHOLDT, A. C. V.; SOUZA, W.; ALVES, E. W.; DAMATTA, R. A. Programmed cell death in Trypanosoma cruzi induced by Bothrops jararaca venom. Memórias do Instituto Oswaldo Cruz, v. 100, n. 1, p. 33-38, 2005. doi: 10.1590/S0074-02762005000100006.

FRYE, F. L. Reptile care: an atlas of diseases and treatments. Neptune: TFH Publications, 1991. practical support from Luciano Antas Bugalho, Jorge Oyakawa, and Cláudio Arroyo, who are experient employees of the Department of Pathology of this School and, finally, Danilo M. Rodrigues and Cristiane Seger for their valuable contributions to image processing. Their work was essential to these results.

HARTMANN, P. A.; TERESINHA, M. T.; GIASSON, L. O. M. Uso do hábitat e alimentação em juvenis de Bothrops jararaca (Serpentes, Viperidae) na mata atlântica do sudeste do Brasil. Phyllomedusa 2, v. 1, n. 2, p. 35-41, 2003. doi: 10.11606/issn.2316-9079.v2ilp35-41.

HELMSTETTER, C.; REIX, N.; T’FLACHEBBA, M.; POPE, R. K.; SECOR, S. M.; LE MAHO, Y.; LIGNOT, J. H. Functional changes with feeding in the gastro-intestinal epithelia of the Burmese python (Python molurus). Zoological Science, v. 26, n. 9, p. 632-638, 2009. doi: 10.1242/jeb.015313.

JACOBSON, E. R. Infectious diseases and pathology of reptiles: color atlas and text. Boca Raton: CRC Press, 2007.

JUNQUEIRA, L. C. U.; CARNEIRO, J. Histologia básica. São Paulo: Guanabara Koogan, 2004.

KHAMAS, W.; REEVES, R. Morphological study of the oesophagus and stomach of the gopher snake pituophis catenifer. Journal of Veterinary Medicine Series C: Anatomia Histologia Embryologia, v. 40, n. 4, p. 307-313, 2011. doi: 10.1111/j.1439-0264.2011.01072.x.

MACHADO, A. B. M.; DRUMMOND, G. M.; PAGLIA, A. P. (Ed.). Livro vermelho da fauna brasileira ameaçada de extinção. Belo Horizonte: Biodiversitas, 2008.

MARSH, N. A. Diagnostic uses of snake venom. Haemostasis, v.31,p. 211-217,2001. doi: 10.1159/000048065.

NEVES, M. S.; SOUSA, D. R. T.; FERREIRA, M. P. S. B. C.; FROTA, M. Z. M.; SOUZA, J. V. B.; LOZANO, J. L. L. Evaluation of antifungal activity of snake venoms from the Amazon forest. Journal of Yeast and Fungal Research, v. 6, n. 2, p. 11-16, 2015. doi: 10.5897/JYFR2014.0146.

Braz. J. Vet. Res. Anim. Sci., São Paulo, v. 54, n. 3, p. 253-263, 2017 
PROPHET, E. B. Laboratory methods in histotechnology. Washington DC: American Registry of Pathology, 1992.

RICARDI, R. Estudo dos mecanismos de supressão da resposta imune induzida pela crotoxina do veneno de Crotalus durissus terrificus. 2010. 75 f. Dissertação (Mestrado em Ciências) - Universidade de São Paulo, São Paulo, 2010. doi: 10.11606/D.42.2010.tde-11082010-143125.

RUDD, C. J.; VISKATIS, L. J.; VIDAL, J. C.; ETCHEVERRY, M. A. In vitro comparison of cytotoxic effects of crotoxin against three human tumors and a normal human epidermal keratinocyte cell line. Investigational New Drugs, v. 12, n. 3, p. 183-184, 1994. doi: 10.1007/BF00873958.

RUSSO, R. R.; MÜLLER, V. D. M.; CINTRA, A. C. O.; FIGUEIREDO, L. T. D.; SAMPAIO, S. V.; AQUINO, V.
H. Phospholipase A2 crotoxin B isolated from the venom of Crotalus durissus terrificus exert antiviral effect against Dengue Virus and Yellow Fever Virus. Virology and Antiviral Research, v. 3, n. 1, 2014. doi: 10.4172/23248955.1000121.

SANTOS, M. M. V.; SANT'ANA, C. D.; GIGLIO, J. R.; SILVA, R. J.; SAMPAIO, S. V.; SOARES, A. M.; FECCHIO, D. Antitumoural effect of an L-amino acid oxidase isolated from Bothrops jararaca snake venom. Basic \& Clinical Pharmacology \& Toxicology, v. 102, n. 6, p. 533-542, 2008. doi: 10.1111/j.1742-7843.2008.00229.x.

SILVA, R. J.; FECCHIO, D.; BARRAVIERA, B. Antitumor effect of snake venoms. Journal of Venomous Animals and Toxins, v. 2, n. 3, 1996. doi: 10.1590/S010479301996000200002 . 